\title{
Difficult Heritage. The Experience of the Fossoli Camp Foundation
}

\section{Marzia Luppi \& Francesca Schintu}

Fossoli Camp Foundation

\begin{abstract}
The historic site of Fossoli Camp is a unique stone witness which still bears the marks left by the central years of the twentieth century. During the Second World War it was a national camp for racial and political deportees, but its story extends to the 1970s when it was used to house civilian orphans and refugees. Today it is a place where history blends with experience and education.
\end{abstract}

The primary goal of the Fossoli Foundation is the protection and preservation of the Camp's heritage, together with its enhancement through activities including research, documentation, and education to promote cultural awareness.

The Foundation focuses especially on close co-operation with schools, developing targeted educational projects and pathways for both students and teachers, with organised visits to its own memorial sites and other European ones. European projects and partnerships represent an increasing part of its activities, and the Foundation is now a member of several national and international networks.

Keywords: Space of Memory, Transit Camp, Concentration Camp, Deportation, Holocaust

\section{Introduction}

The aim of this paper is to present the history of an Italian internment camp built during the Second World War and to follow its subsequent changes of use and explore the extent to which they reflect the changing political circumstances in both a national and international context in the post-war years. In particular, it describes how the Fossoli Foundation determines its research, documentation, and training work, starting from its principal priority of protecting and enhancing this complex historical site.

Fossoli is a significant place in terms of the relationship between history and memory, a memory that developed further when the camp structures were used to house Julian- 
Dalmatian refugees. Over time, the story of the camp evolves from that of a symbolic place of the Resistance (the typical narrative of the 1950s) to one which incorporates a multiplicity of memories arising from its subsequent history.

This paper is based on historiographical sources and testimonies as well as the direct experience of the site's management team. Since its creation in 1996, the Fossoli Camp Foundation has been committed to enhancing the history and heritage of the former Fossoli concentration and transit camp through the preservation of a complex memory space. The heritage assets of the Foundation also include an important museum dedicated to political and racial deportees, an archive, and the old synagogue of Carpi.

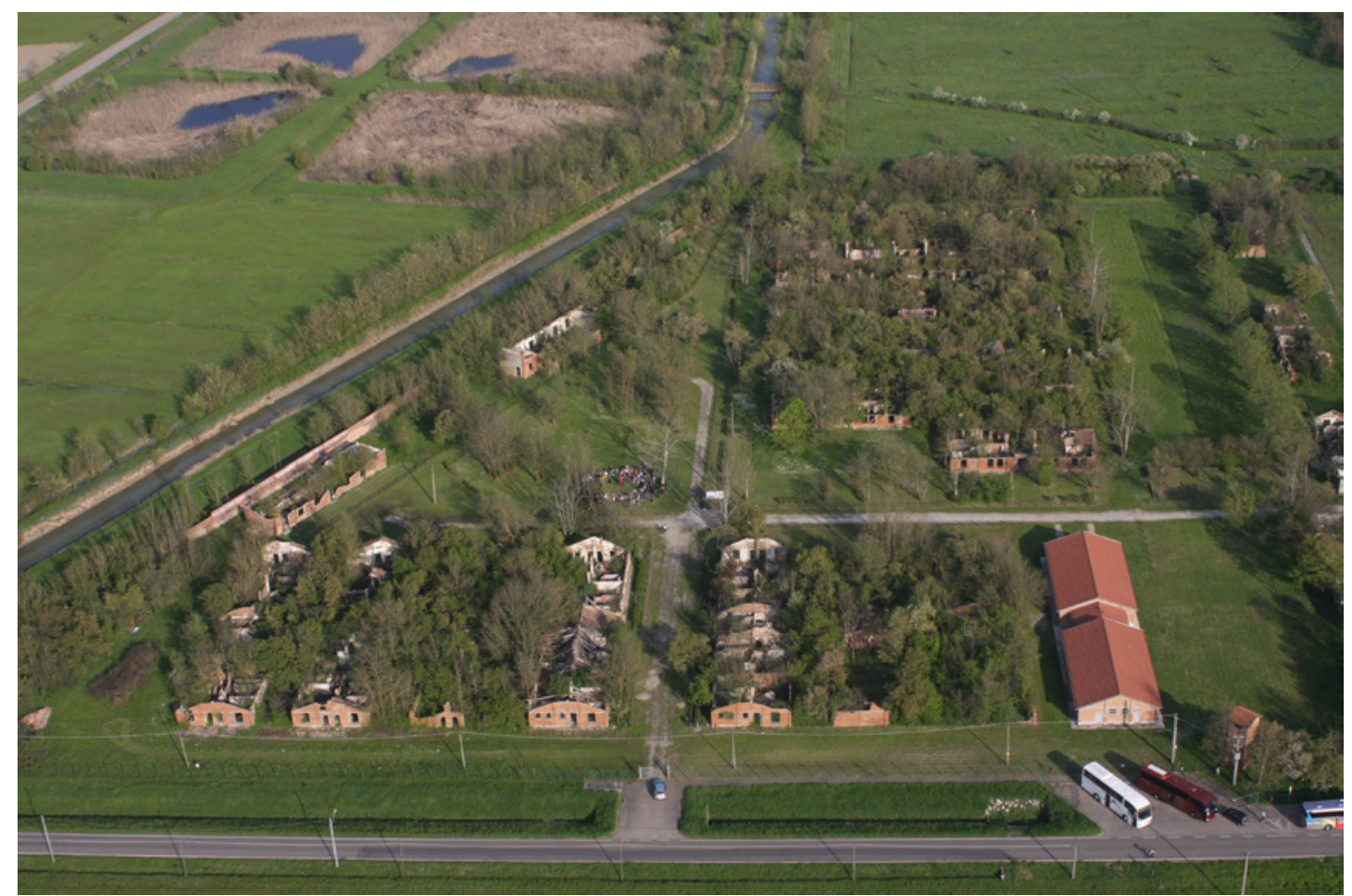

Figure 1. Aerial photograph of Fossoli Camp. Photographic archive of the "Primo Levi" Study and Documentation Centre - Fossoli Foundation (Csd-FF).

Fossoli Camp is located in the hamlet of Fossoli, which is situated in the countryside about six kilometres from Carpi city centre, near Modena in northern Italy. It is a site of many memories, given the many functions that the place has fulfilled over time. It is also a place with an historical significance that stretches beyond the Italian border.

Constructed during the Second World War, it has served several functions during its long history, initially as a result of the upheavals of war and later through the transition to peace and democracy. In its 28-year history, from 1942 to 1970, it has had seven different phases of use, followed by a long period of neglect and decay.

The present condition of the site reflects these multiple uses, the surviving area today being much modified compared to its appearance during the war years (1942-45) through rebuilding, restoration, and the growth of vegetation. In the space of nearly 30 years, the camp witnessed prisoners, internees, forced labourers, orphans, and refugees passing 
through. A variety of people were brought to Fossoli through the events and consequences of the war, which continued to affect civilians well after it ended.

Fossoli Camp was originally composed of two areas: the Old Camp and the New Camp. The Old Camp, which was constructed three months before the New one, was demolished in 1946, so the camp seen today on Remesina Road is the New Camp.

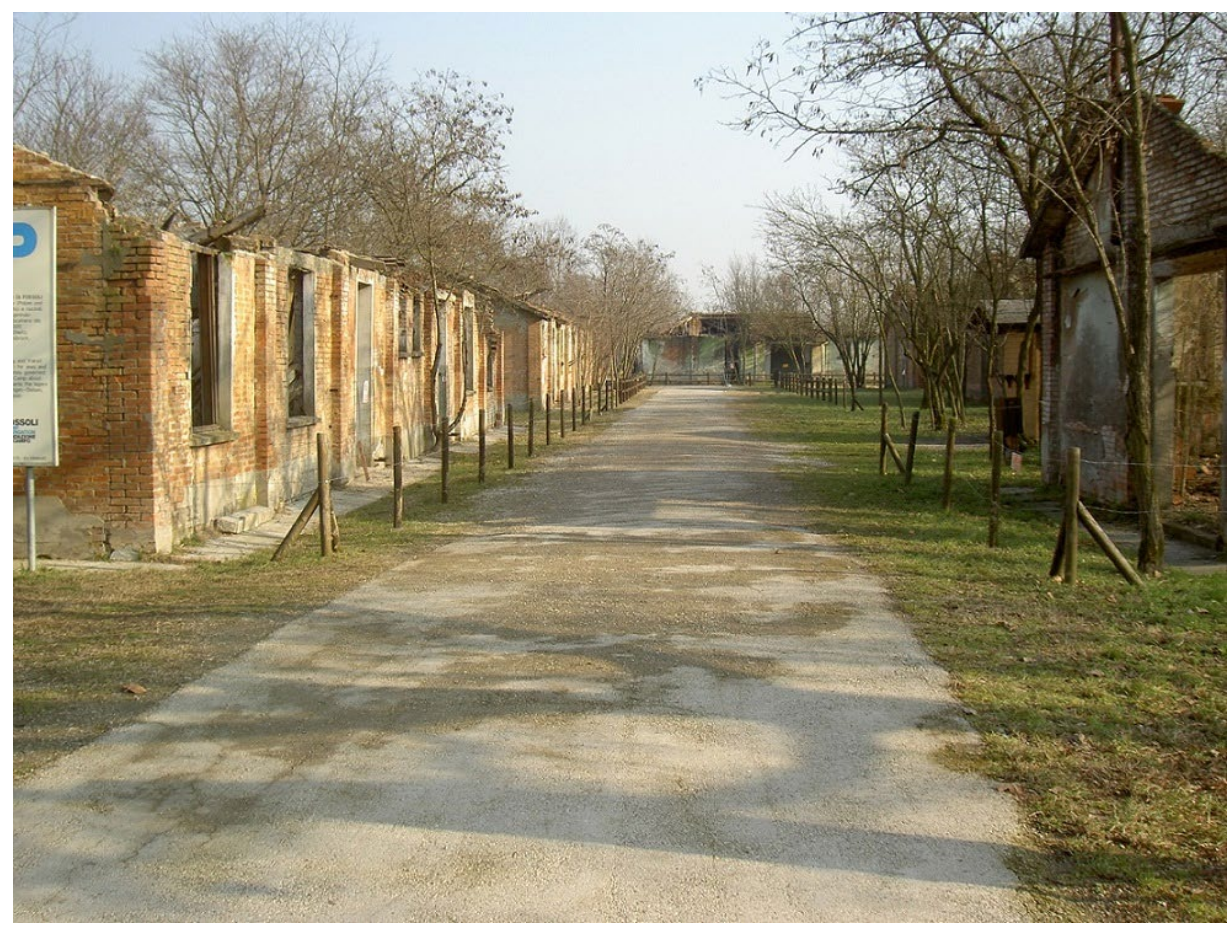

Figure 2. View of Fossoli Camp. Photographic archive Csd-FF.

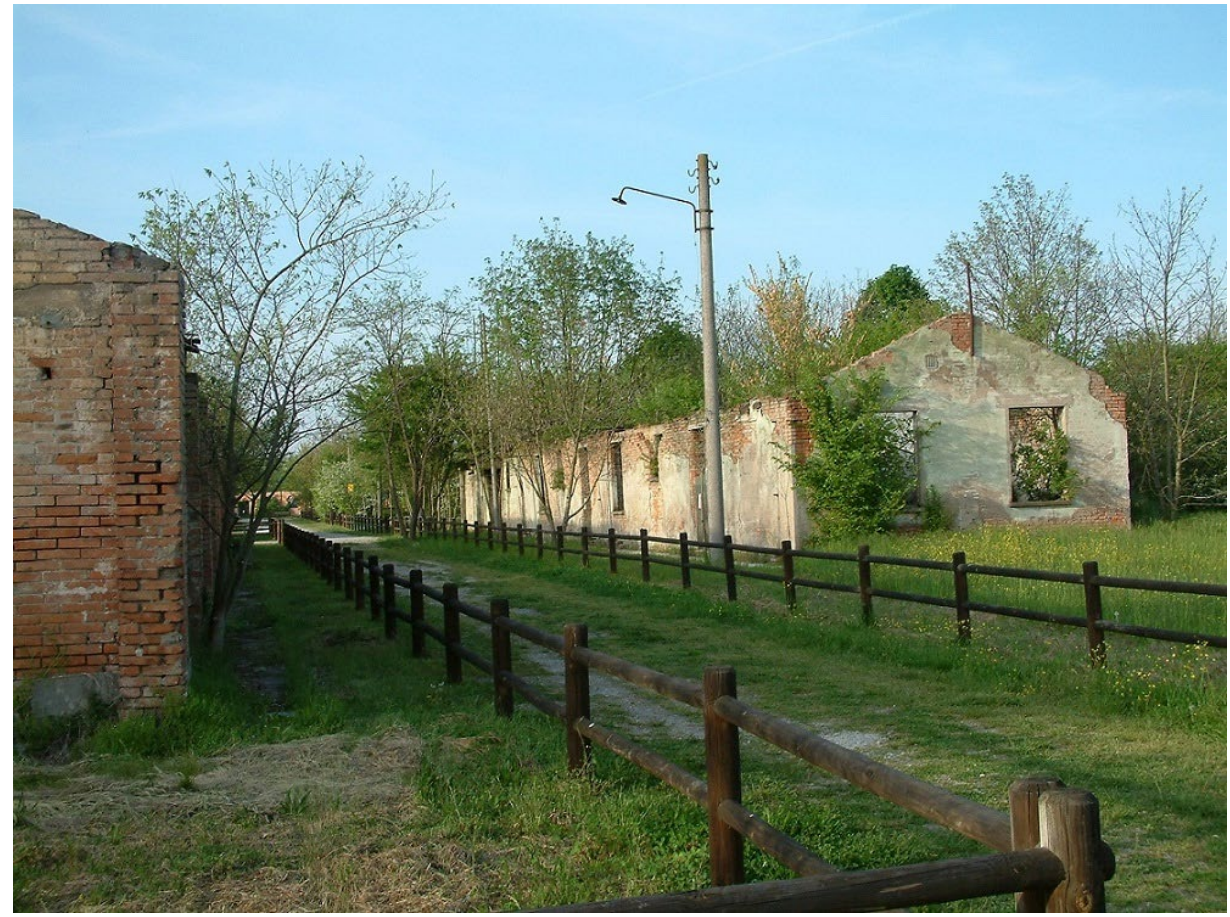

Figure 3. View of Fossoli Camp. Photographic archive Csd-FF. 


\section{Prisoner of War Camp - PG No.73}

During the war, from spring 1942 to 8 September 1943, Fossoli was a prison camp (PG No. 73) where Allied soldiers and non-commissioned officers captured in North Africa British, New Zealand, African and Australian - were interned. Their imprisonment was regulated by the international Geneva Convention rules for prisoners of war. When the first prisoners started to arrive in July 1942, the brick huts were not finished and a tented camp was erected in the area facing Remesina Road. Once the facility was completed (93 huts in the Old Camp on Grilli Road and 30 in the New Camp on Remesina Road), the number of prisoners reached 5000. Life in the camp seemed to be acceptable, as one testimony recalls:

"The food was fairly good, everyone contributed with a penny to buy musical instruments and play a concert, once a week the Italian guards took a hundred prisoners to the countryside for a healthy march, we would regularly receive packeages from the Red Cross." (Luppi 2010: 26).

The prisoners' conditions worsened during the winter season when mud, cold, and parasites made living in the huts miserable and unbearable.

In July 1943, King Victor Emmanuel III deposed Mussolini and appointed a new government under Marshal Pietro Badoglio that was prepared to sign an armistice with the Allies. When the armistice was made public on 8 September 1943, the Germans occupied northern and central Italy, released Mussolini from imprisonment and appointed him as head of the Italian Social Republic, a puppet state in German-occupied northern Italy.

"I was in the camp when I received the good news that the British and American forces had invaded Italy [...] The thought of freedom didn't let a single prisoner sleep that night. But the good news didn't last long and the big surprise came the day after when the German tanks appeared." (Luppi 2010: 28).

This is how James Moore, a military prisoner at Fossoli, recalls 8 September. After the armistice the German army took the camp by force, disarming the Italian garrison and moving the prisoners and the Italian guards to camps located in Germany. The latter, together with over 650,000 Italian soldiers and officers captured by the German forces, were classified as Italian Military Internees (IMI) rather than prisoners of war and were interned in prison camps and forced to live and work in brutal conditions (Minardi 2016). The camp was not abandoned though, and it continued to play a key role in the persecution policy that Nazi-Fascism used against many people. Italians faced deportation on many different grounds during the final phase of the war: Jews, anti-fascists, opponents of the regime, homosexuals, gypsies, strikers were all persecuted and moved to Nazi concentration camps. 


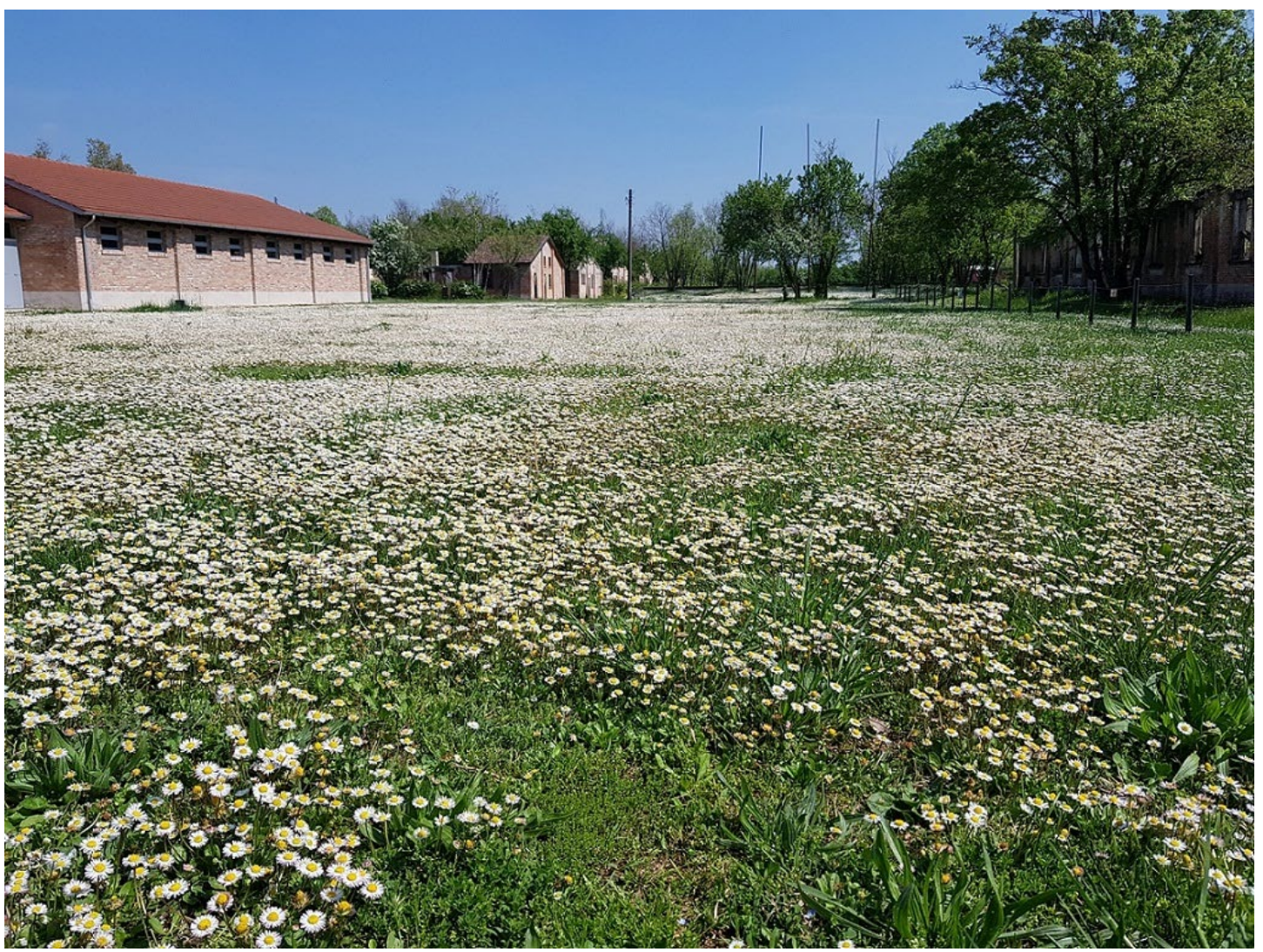

Figure 4. View of Fossoli Camp. (Photographic archive Csd-FF.

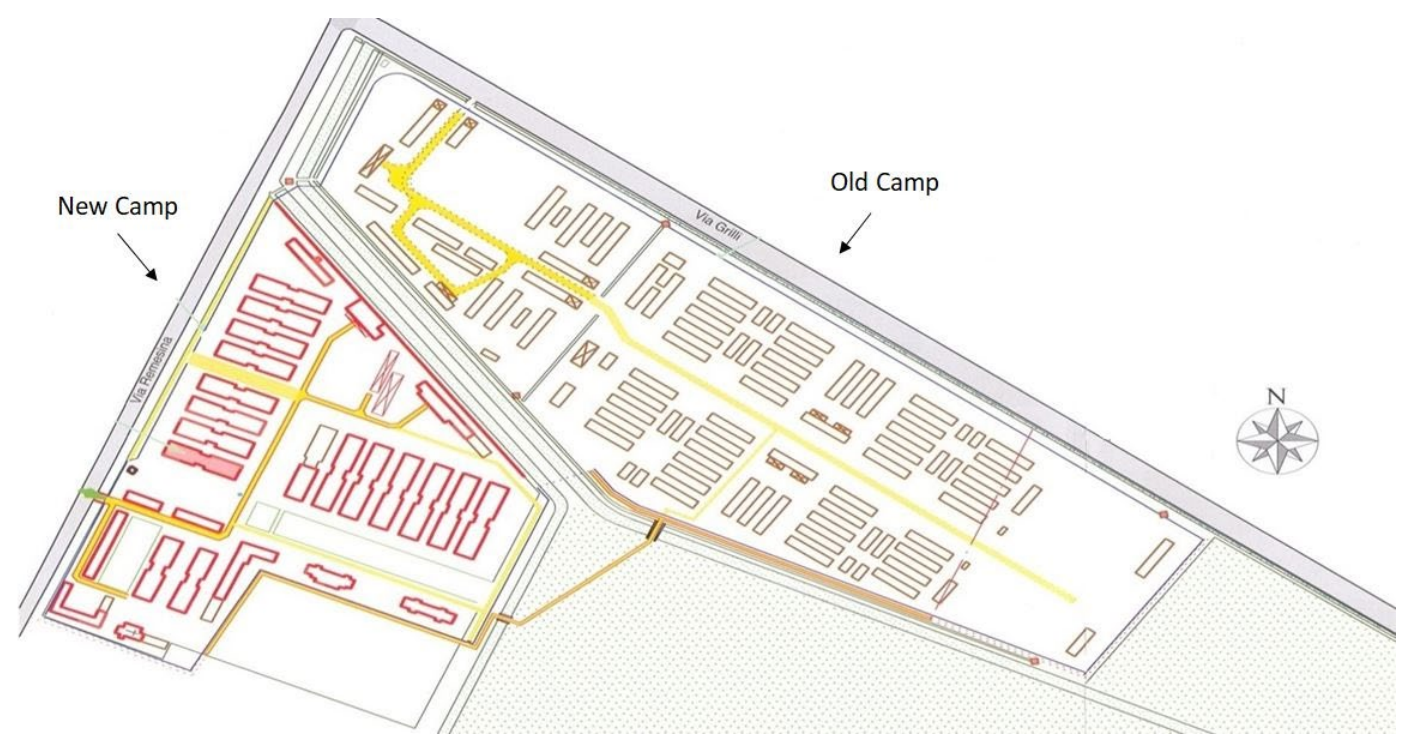

Figure 5. Map of the Fossoli Camp. Photographic archive Csd-FF.

\section{National concentration camp for racial and political deportees}

In early December 1943, the second use of the camp began: Fossoli became a special internment camp for Jews detained in Italy, in compliance with the Manifesto of Verona, issued on 14 November 1943 by the Republican Fascist Party, which stated at point seven: "Those belonging to the Jewish race are foreigners. During this war they belong to an enemy nation." (Luppi \& Tamassia 2016: 7). This was combined with police ordinance 
no. five, issued by the Italian Social Republic on 30 November 1943, which stated that all Jews who were in Italy were to be sent to provincial concentration camps and then transferred to a new national concentration camp for Jews. Fossoli was chosen to become the national concentration camp for those detained on the grounds of race.

The first group of Jews, mainly consisting of families, arrived in Fossoli in the early days of December 1943, but their number would soon rise exponentially. From February 1944, political opponents, partisans and anti-fascists also started to arrive. During this phase total segregation of internees was not enforced: builders responsible for maintenance, farmers and food suppliers also had access to the camp. Don Francesco Venturelli, the parish priest of Fossoli, regularly visited the camp to assist the prisoners and did his best to bring them help and comfort.

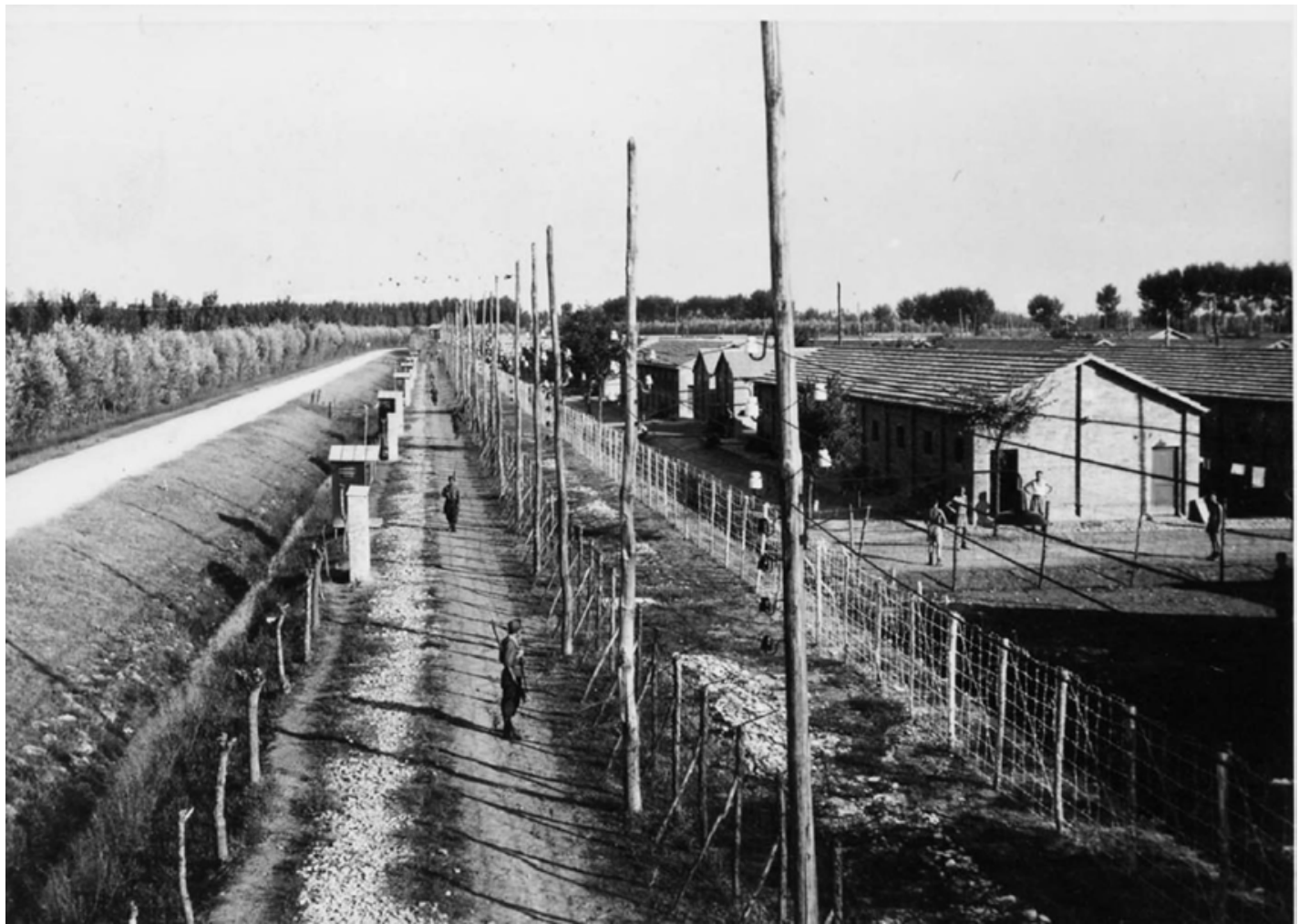

Figure 6. Fossoli Camp, 1943. Photographic archive Csd-FF.

Primo Levi was an Italian Jewish chemist, writer, and Holocaust survivor. He was interned in Fossoli Camp in January 1944. In the first pages of his novel If This Is a Man, he recalls his brief detention in Fossoli before leaving for Auschwitz extermination camp in Nazioccupied Poland. From among the 650 Italian Jews in his transport, Levi was one of only 20 who left Auschwitz alive. Sunset at Fossoli is the title of the poem that Primo Levi wrote when he returned to Italy. Levi was sent to Auschwitz when Fossoli camp was under Fascist control, which raises questions about Italy's role in the deportation chain.

Fossoli Camp became the main Italian transit camp for political and racial deportees. Between 26 January and 1 August 1944, over 2800 Jewish people and over 2600 political 
prisoners were moved from here to Nazi concentration and extermination camps: Jews were sent to Auschwitz, Bergen Belsen, Buchenwald, and Ravensbrück, while political opponents were moved to Mauthausen, Flossenbürg, and Dachau.

It must be borne in mind that Fossoli was a well-placed, efficient link in the geography of deportation. According to the latest studies, we know that 12 train convoys for transporting Jews and three for political internees left Carpi railway station (Picciotto 2010; D’Amico et al. 2010). Primo Levi was on the one which left on 22 February 1944.

\section{Polizei-und Durchgangslager / Camp for civilian internees}

The third phase of the camp's use began on 15 March 1944: from this date onwards we must refer to two Fossoli camps, which occupied two distinct and separate areas, fulfilled different roles, and were administered by two different state agencies.

The New Camp became the Polizei-und Durchgangslager, a transit camp for political opponents and Jewish people, managed by the Nazi Security Police Headquarters based in Verona. The Camp was in turn divided into two sectors - the Jews' camp and the political internees' camp - separated by a mesh fence to prevent any possible contact between them.

The Old Camp, meanwhile, became a concentration camp for civilian internees which fell under the authority of the Police Headquarters in Modena and essentially fulfilled public safety purposes. The prisoners of the Old Camp (citizens of enemy nationalities, parents of national service dodgers, and common convicts) were not ordinarily destined to be deported, but various testimonies document that civilian internees who were considered dangerous were taken out of the Italian camp and added to the trains bound for the camps of the Reich. Little is known of how the Italian authorities managed this area of the Camp as it was demolished in 1946, nor how many people were confined, abused or killed (Ropa 2016).

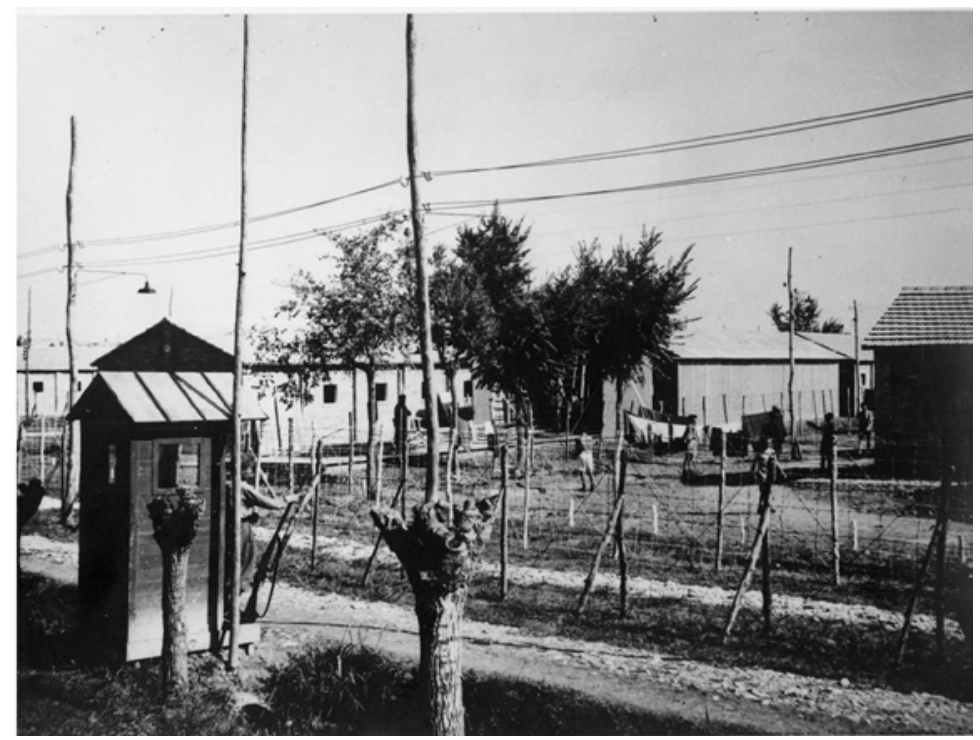

Figure 7. Fossoli Camp, 1943. Photographic archive Csd-FF. 
Much remains to be investigated about the relationship between the two camps, the respective authorities - Nazi and Fascist - and their apparatuses; in part due to the lack of testimony, the memory of civilian internment has not left distinct traces in the collective memory and for a long time that period was not included in the historiography of Fossoli. The police and transit camp, one step along the extreme experience of deportation and extermination, ended up representing the entire series of events at Fossoli Camp during the war, obscuring the other steps. Likewise, for a long time historiography left Italian responsibility for the site in the shadows, or limited it, perpetuating the conventionally accepted idea of the good Italian (Focardi 2013).

During the period under Nazi control, the regime at the New Camp was marked more and more frequently by abuse and violence towards prisoners. The discipline grew stricter and stricter and the segregation was total. We know that upon entering the camp all the prisoners had to be registered and were given their distinguishing badge that they had to sew onto their clothes: a yellow band for Jews, a red triangle with a registration number for political dissidents. The ordinary maintenance work on the camp was performed by the internees, even that in the offices of the German administration. The personal files of those who were sent to Fossoli were compiled by some female internees who had to record internees' particulars, home address, and place and day of arrest. These files have never been found; as a result, reconstructing the list of those who passed through Fossoli has required a lengthy research project that is yet to be completed. ${ }^{1}$

On the evening of 11 July 1944, after roll call, 71 political internees - all men of different ages and political affiliations from various regions of Italy - were notified that they were to prepare to depart for Germany by order of the Verona Gestapo. At dawn on 12 July, 69 prisoners were loaded in three groups onto trucks and led to the Cibeno shooting range, a few kilometres from Fossoli, where they were shot at the edge of a mass grave that some Jewish internees had been forced to dig the previous day. Four men survived: Bernardo Carenini was left off the list and Teresio Olivelli managed to hide inside the camp, while Eugenio Jemina and Mario Fasoli escaped execution by rebelling. Before the execution, the death sentence had been pronounced in retaliation for an attack on German soldiers in Genoa. Historians have cast doubt on this motivation due to its many inconsistencies: in terms of time, because the massacre in Liguria had occurred a few days earlier; in terms of place because the distance from the attack nullifies the demonstrative purpose of the retaliation; and as a deterrent, because great lengths were taken to conceal the massacre from the population.

\footnotetext{
${ }^{1}$ Reconstructing at least the names of those who travelled through the Fossoli camp between 1942 and 1944 is a long-term research project that the Fossoli Foundation began in 2008, with the research group composed of Marco Minardi, Roberta Mira, and Rossella Ropa, leading to the construction of the database 'I Nomi di Fossoli' (The Names of Fossoli): http://www.centrostudifossoli.org/i-nomi-di-fossoli.php.
} 
On 17 and 18 May 1945, less than a month after the Liberation, the 67 victims were disinterred and identified. Solemn funeral rites for those killed were held in Milan cathedral on 24 May 1945, with large crowds of emotional citizens in attendance.

The advance of the front line, the danger of bombings, and the escalation of the partisan fight made the camp unsafe and difficult to control, so at the end of July, the German command decided to close it down and move the internees to Gries Camp, in the suburbs of Bolzano. The entire German Headquarters was transferred to Gries, along with the last remaining internees who would be deported from Bolzano over the following days. Gries Camp was active from the summer of 1944 until the end of the war (Venegoni 2004; Di Sante 2019).

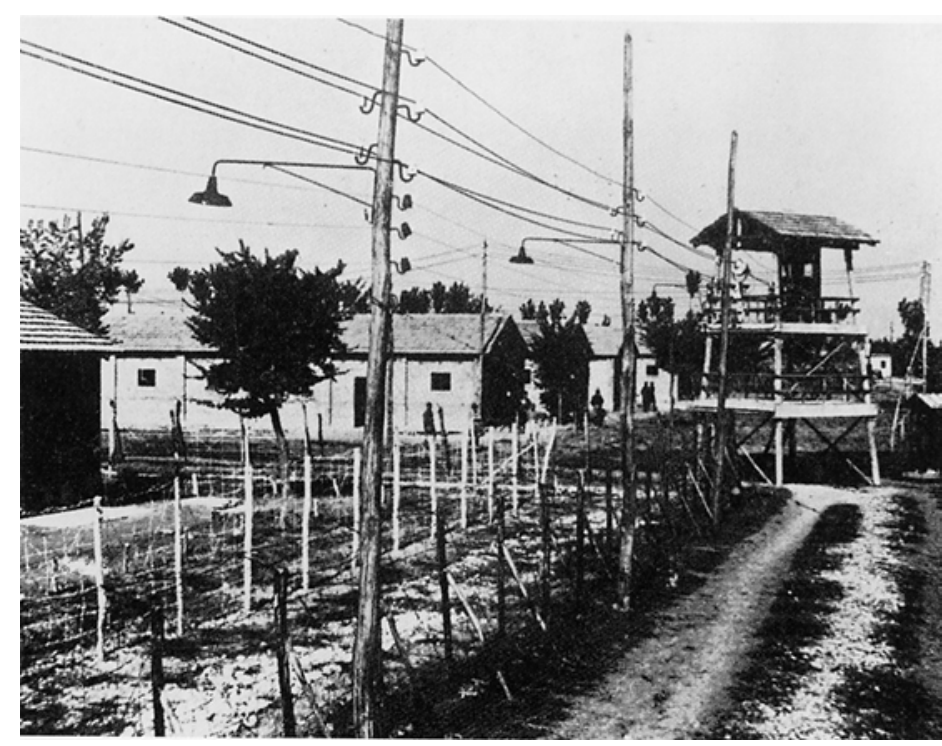

Figure 8. Photograph of the watchtower located in the external perimeter of the Fossoli Camp, 1943. Photographic archive Csd-FF.

\section{Forced labourers collection camp}

Nevertheless, the camp remained under the German General Plenipotentiary for Manpower: from August to November 1944, it operated as a transit site for labourers forced to work in the manufacturing plants of the Third Reich. This is the fourth phase of the camp; according to some estimates, between 5000 and 10,000 people passed through during this phase, which ended in November 1944 when the Allies bombed the camp (Mira 2016).

The camp's activities continued after the end of the war until the 1970s. It went through the difficult transition of the post-war period and some crucial historical events of those years.

\section{Foreign refugees' collection centre}

In 1946 the Old Camp was demolished, and the area returned to its former use as farmland; the New Camp was restored in the early months after the Liberation as a prison to hold Fascists, disbanded soldiers from the defeated forces, and individuals considered dangerous. From March 1946, the Allied authorities began sending stateless persons, 
concentration camp survivors, refugees of various origins, and soldiers from the defeated armies to the camp. Until 1947, Fossoli was one of six collection centres for 'Undesirable Foreigners' in Italy managed by the Ministry of the Interior (Di Sante 2011). The painful and dramatic inheritance of totalitarian demographic policies and of a war that had devastated the lives of civilians was an army of refugees, of displaced persons wandering through a destroyed Europe. Many reports and requests for help document the ungovernable situation inside the fences of Fossoli. Significantly, this was the period in which a high boundary wall was built that delimited the area and isolated it, even visually, from the surrounding countryside.

The collection centre for foreigners is the final chapter of the wartime events in Fossoli. What happened from 1947 to 1970 belongs to the post-war period, even though Fossoli and Carpi continued to carry the burdensome inheritance that the war left to the town.

\section{Nomadelfia}

When the collection centre was vacated, the empty facilities were occupied by Don Zeno Saltini's 'Opera Piccoli Apostoli'. A lawyer, priest, and educator, Don Zeno Saltini (b. Fossoli di Carpi, 30 August 1900 - d. Nomadelfia, Grosseto, 15 January 1981) became parish priest in a town near Modena where he began to gather young, displaced orphans - the Piccoli Apostoli (Little Apostles). In 1947, he moved some one hundred youths belonging to the Opera Piccoli Apostoli to the Fossoli Camp; their numbers would soon exceed 800. The community, whose founding document was signed in Fossoli in February 1948, was significantly named 'Nomadelfia'; it was composed of young people and 'mothers by vocation' and would remain based in Fossoli until 1952. Over this period the brick huts were restored and the most evident signs of confinement from the war years were demolished: walls, barbed wire, watchtowers.

Nomadelfia was an extraordinary establishment, filled with excitement for its future plans, reflecting an Italian society that sought tenaciously to distance itself from a devastating war and found itself anew. This experience would soon clash with the situation in Italy, which was increasingly ideologically polarised, being part of a Europe divided by the Cold War. Nomadelfia encountered opposition on both sides of the ideological divide, as well as economic challenges which in 1952 led the community to move to the hills outside Grosseto, where it continues to this day, following the principles of communal living and working that inspired the first community (Rinaldi 2003).

\section{St. Mark's village}

The following year, 1953, the welfare institution for Julian-Dalmatian refugees rented the area to host Italian refugees from Istria. In 1954, the London Memorandum assigned Trieste to Italy and Istria to Yugoslavia to resolve the question of Italy's eastern border; no fewer than 250,000 Italian exiles fled those lands and were either housed in 20 refugee camps in Italy or migrated towards other countries (Cattaruzza 2007; Bresciani \& Orlić 2011). Over 150 Istrian families arrived in Fossoli, then called Villaggio San Marco; in addition to the pain of exile, they had to face difficult integration into a community which 
was mostly unaware of their vicissitudes, which often failed to understand the reasons for their migration, and which saw their presence as a threat to already uncertain work opportunities. All these factors made the integration of the two communities long and difficult. In addition, the refugees perceived their placement in a former concentration camp, (albeit partly modified by the renovations done by the Nomadelfia community), as further evidence of their marginalisation and exclusion. The story of this village, which represents the longest period of occupation of the camp, was long ignored, forgotten alongside the phenomenon of the Julian-Dalmatian exodus. The Istrians lived in the former concentration camp buildings for over 15 years, leaving a profound mark: the barracks were converted into houses, schools, workshops, and manufacturing plants; one became the parish church of the village; the open spaces became gardens, vegetable patches, football pitches. All these transformations helped to foster the integration of the Istrian families into the town's society. In 1970, the last Julian families left Villaggio San Marco and moved to Carpi city centre (Molinari 2006). The camp was then abandoned until 1984, when the Municipality of Carpi became its owner.

\section{Between history and memory}

In the years that followed the Villaggio San Marco period, the camp rapidly became derelict. The work of the Fossoli Camp Foundation, founded in 1996, managed to halt part of the deterioration and collapse, which worsened in 2012 due to earthquakes and heavy snowfall. In 2004, Hut no. 14, in the Jewish sector of the New Camp, was rebuilt and restored to its original appearance. Today, only a small portion of the original camp remains, but sufficient to allow us to catch a glimpse of 30 crucial years in Italian, war, and reconstruction history.

In 2012, the Fossoli Foundation, in partnership with the Municipality of Carpi and the Ministry of Cultural Heritage (MiBACT) and with the help of the University of Bologna, launched a project for the conservation and enhancement of the site. A large number of professionals (experts in restoration, construction practice, botany, garden maintenance, etc.) have been called in to carry out inspections, monitoring, and conservation work at regular intervals, on both the buildings and the landscape. The extremely fragile remains of what constitutes the architectural part of the camp are in fact surrounded, and in some cases overrun, by vegetation (Ugolini \& Delizia 2017).

Fossoli undoubtedly remains an unusual case among Holocaust sites because it is an historical site, an archaeological site, and a place of memory, all at the same time. The project is guided by the principle of auxiliary intervention on existing structures, strengthening a structural system where attempts to repair what remains. The repair work is minimal, designed to provide the existing buildings with a level of construction quality that will lead, with future improvements, to successful protection against earthquakes and durability against the wear-and-tear of time (Ugolini \& Delizia 2017).

To date, four huts have been made safe and visitors can finally enter these. The next step is to build a visitor centre with digital devices to enrich the visitor experience. 


\section{The Museum and Monument dedicated to the Political and Racial Deportee to the Nazi Death Camps}

The presence of Fossoli Camp was at the root of the creation of the Museum and Monument dedicated to the Political and Racial Deportee to the Nazi Death Camps. It is the first museum of this kind in Italy.

On the tenth anniversary of the Resistance, in 1955, when deportation was still a littlediscussed phenomenon not just in Italy (Lagrou 2003), the Municipality of Carpi organised an impressive event in Carpi to celebrate the Resistance in the Extermination Camps and held the first national exhibition on deportation to Nazi concentration camps. This exhibition was destined to change Italy's perception of the phenomenon of deportation. In 1961, on the occasion of the hundredth anniversary of the unification of Italy, the exhibition returned to Carpi with new documents, contributions, and knowledge (Luppi \& Ruffini 2005).

In the few years between the two exhibitions there had been a shift in both cultural and civil attitudes, with public sensitivity towards the phenomenon of deportation becoming more attentive and receptive (Gordon 2013). It was then possible to go beyond occasional moments of remembrance and periodic celebrations to begin building something more lasting: the Museum and Monument to the Political and Racial Deportee.

On 14 October 1973, after 10 years of work to restore and redesign the Castello dei Pio in the historic city centre of Carpi, the Museum-Monument was opened by the President of the Republic during an event whose ceremony evoked those of 1955 and 1961 (Luppi \& Tamassia 2016).

The architects who designed the Museum-Monument (BBPR Studio), like many artists and other key figures involved in its creation, construction and decoration, were also witnesses to the events that they depicted; in their work, we sense the urgent need to provide solid, physical reminders as tools to fight against oblivion. At the end of the text by Primo Levi that forms the introduction to the first catalogue of the MuseumMonument in 1973, we read:

"Here we touch the depths of barbarism, and it is our hope that what is documented here be seen and remembered as an aberration not to be repeated into the most distant future."(Steiner 1973: 4).

Thus, from the beginning, Fossoli Camp and the Museum-Monument established a relationship that connects the physical, historical site to the representation of those events to convey the knowledge of the past to present and future generations. The creation of the Museum is a major milestone in the creation of a memory system around Fossoli and it has led to the development in the Carpi area of an educational trail designed to aid visitors' understanding of history through significant places. 


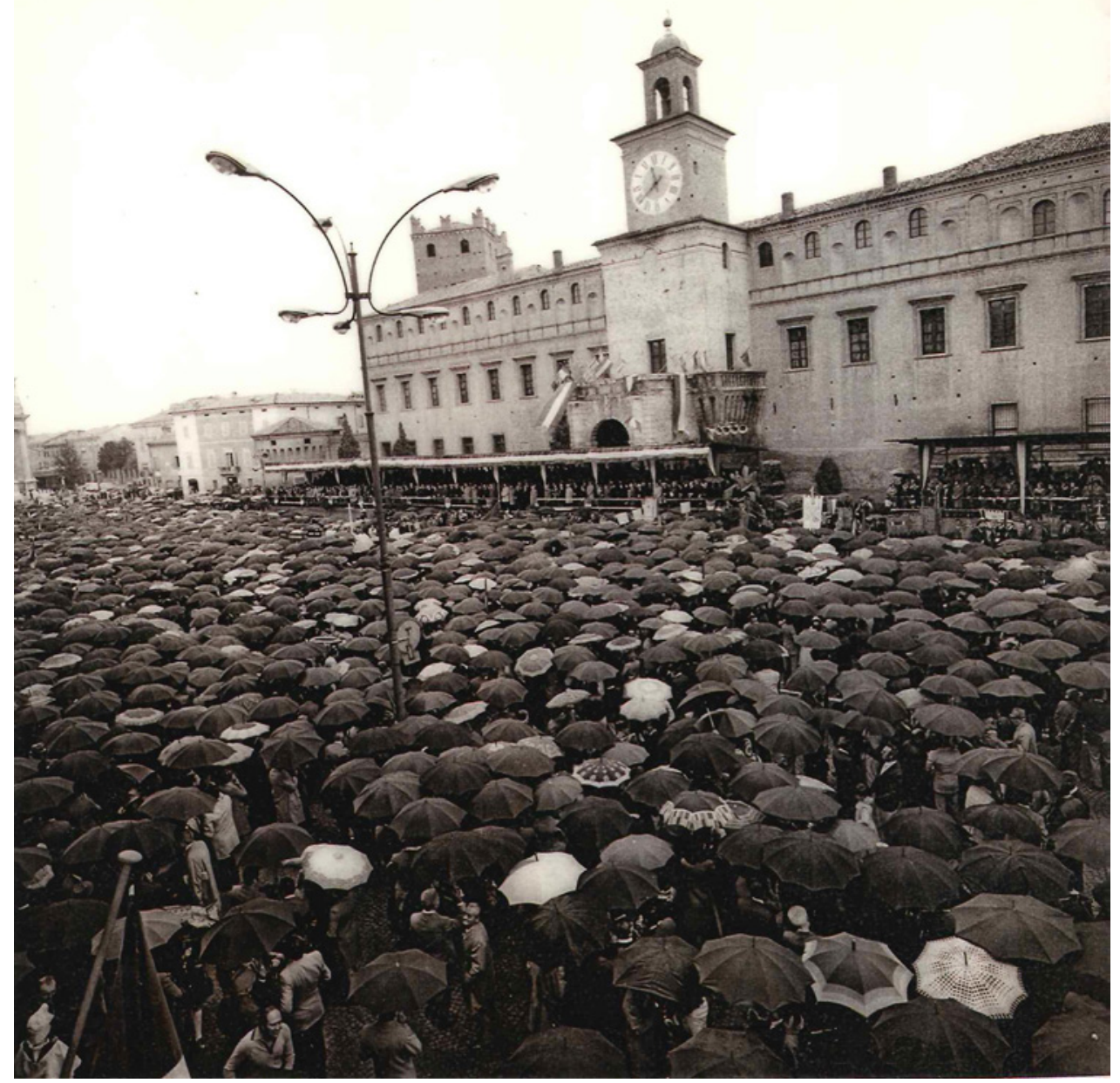

Figure 9. Inauguration of the Museum and Monument to the Racial and Political Deportee, 14 October 1973. Photographic archive Csd-FF.

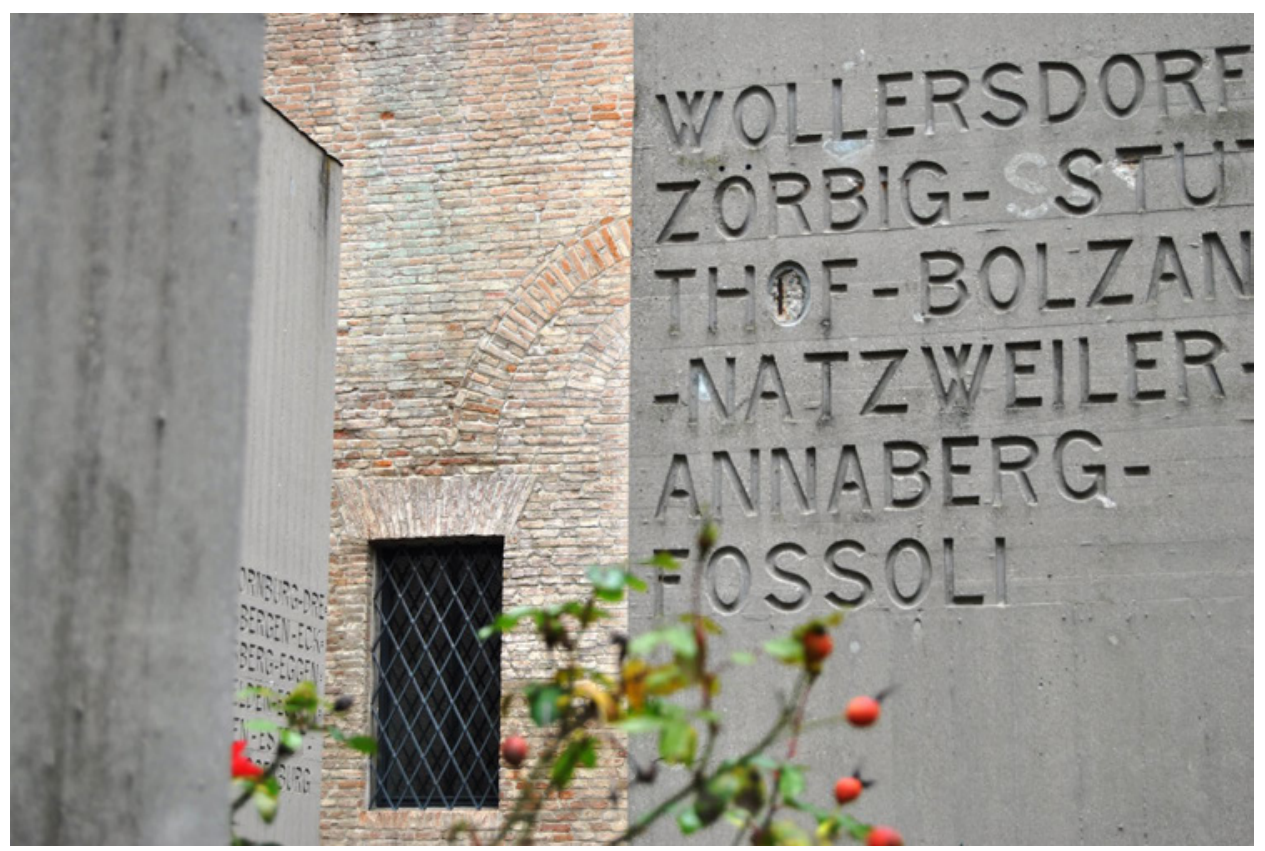

Figure 10. Detail of the Courtyard of the Stele, Museum and Monument to the Racial and Political Deportee. Photographic archive Csd-FF. 


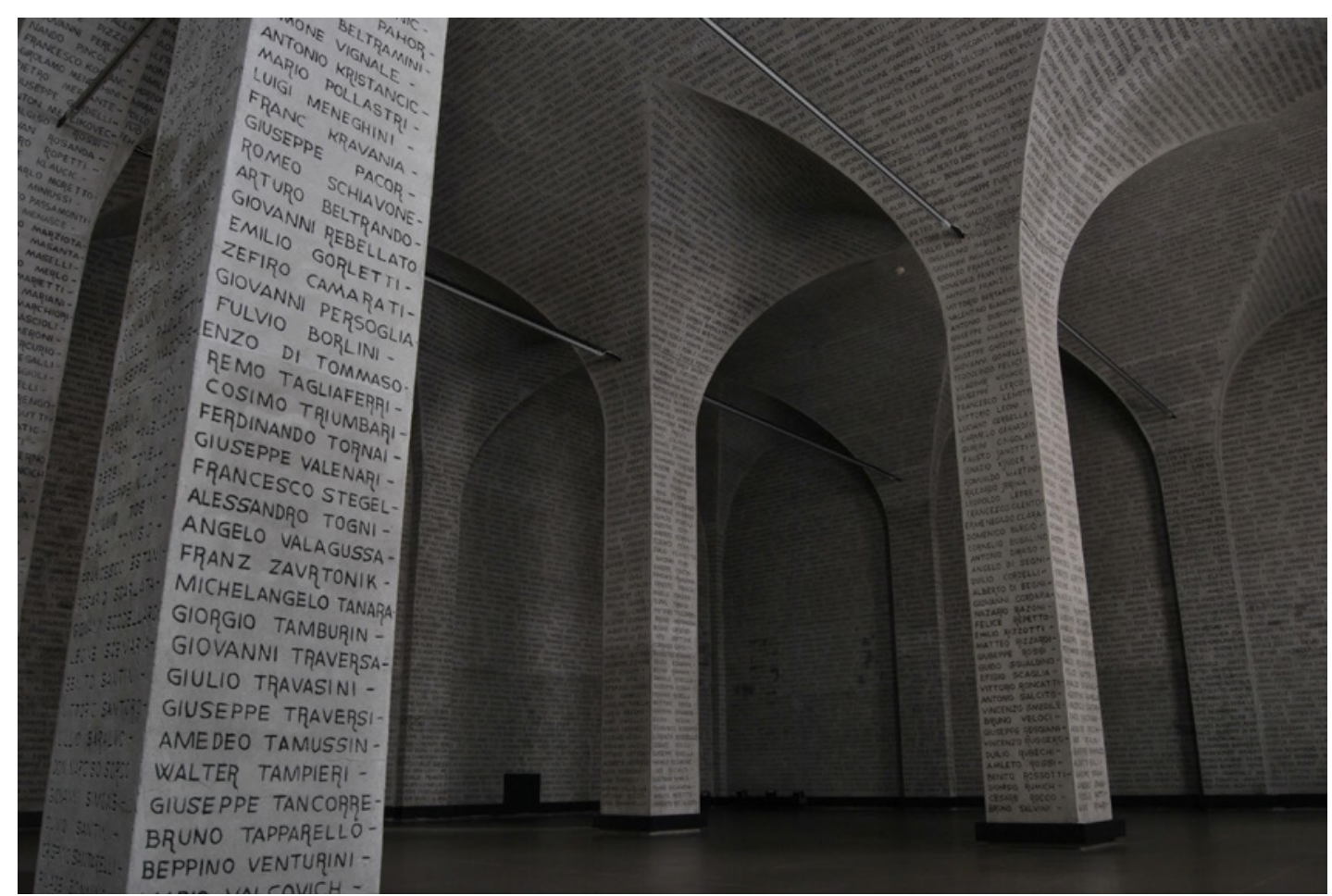

Figure 11. Hall of Names in Museum and Monument to the Racial and Political Deportee. Photographic archive Csd-FF.

\section{Fossoli Camp today}

In 1996, the Fossoli Camp Foundation began an intense educational programme on memory and human rights. Among the tasks set out in its charter, the Fossoli Foundation aims to protect and increase the value of both the camp and the Museum-Monument (managed by the Foundation since 1996 and 2001 respectively); to promote historical and documentary research on Fossoli Camp; and to plan and activate initiatives of a popularising, educational, and scientific nature.

The key priority is to make guided visits effective and to underscore the multitude of memories. Today Fossoli Camp is visited by over 40,000 people every year.

The main goal is to produce, through the conservation and enhancement of a complex memory space, different reflections not only about our past but also about our contemporary society, using art and education as the primary tools.

\section{References}

BresCiAni M. \& ORLiĆ M. 2011. Il confine orientale e i conflitti dell'alto Adriatico. Bibliografia ragionata. Milano: Unicopli.

CATTARUZZA M. 2007. L'Italia e il confine orientale, 1866-2006. Bologna: il Mulino.

D'Amico G., Villari G. \& Cassata F. 2010. I deportati politici 1943-1945, in: B. Mantelli \& N. Tranfaglia (eds.), Il libro dei deportati, 3 vols. Milano: Mursia.

Di SANTE C. 2011. Stranieri indesiderabili. Il Campo di Fossoli e $i$ "centri raccolta profughi" in Italia 1945-1970. Verona: Ombre Corte. 
Di SANTE C. 2019. Criminali del Campo di concentramento di Bolzzano. Deposižioni, disegni, foto e documenti inediti. Bolzano: Edition Raetia.

FOCARDI F. 2013. Il cattivo tedesco e il bravo italiano. La rimozione delle colpe della seconda guerra mondiale. Roma-Bari: Laterza.

GORDON R.S.C. 2013. Scolpitelo nei cuori. L'Olocausto nella cultura italiana (1944-2010). Torino: Bollati Boringhieri.

LAGROU P. 2003. Mémoires patriotiques et occupation nazie. Résistants, requis et déportés en Europe occidentale, 1945-1965. Bruxelles: Complexe.

LUPPI M. \& RUFFINI E. 2005. Immagini dal silenzio. La prima mostra nazionale dei lager nazisti attraverso l'Italia 1955-1960. Carpi: Nuovagrafica.

LupPI M. 2010. Il Campo di Fossoli: un patrimonio per educare, in: Tempi di scelta. Storie di 4 luoghi. A project by Assemblea Legislativa della Regione Emilia Romagna and Anna Frank House. Amsterdam.

LupPi M. \& TAMAssia P. (eds.), 2016. Il Museo Monumento al Deportato politico e razziale di Carpi e l'ex Campo di Fossoli. Bologna: Bologna University Press.

MinARDI M. 2016. I nemici. I prigionieri del PG 73. Accessed 5 Oct 2020 http://www.centrostudifossoli.org/PDF/dbminardi.pdf

MirA R. 2016. Il Campo di Fossoli e il reclutamento di forza lavoro per la Germania nazista. Accessed 5 Oct 2020 http://www.centrostudifossoli.org/PDF/dbmira.pdf

Molinari M. L. 2006. Villaggio San Marco - via Remesima 32 Fossoli di Carpi. Torino: Ega Editori, Quaderni di Fossoli.

PicciotTo L. 2010. L'alba ci colse come un tradimento. Gli ebrei nel Campo di Fossoli 1943-1944. Milano: Mondadori.

RINALDI R. 2003. Storia di Don Zeno e Nomadelfia, 2 vols. Grosseto: Nomadelfia Editori.

RopA R. 2016. Il campo italiano. Accessed 5 Oct 2020 http://www.centrostudifossoli.org/PDF/dbropa.pdf

STEINER L. \& STEINER A. 1973. Museo monumento al deportato politico e razziale nei campi di sterminio nazisti. Sesto San Giovanni: G. Beveresco, 1973.

Ugolini A. \& Delizia F. (eds.), 2017. Strappati all'oblio. Strategie per la conservazione di un luogo di memoria del secondo Novecento: l'ex Campo di Fossoli. Firenze: Altralinea Edizioni.

VENEGONI D. 2004. Uomini, donne, e bambini nel Lager di Bolzano. Una tragedia italiana in 7.982 storie individuali. Milano: Mimesis. 
